\title{
Advertising Strategy of Coca-Cola at Coca-Cola Beverages Pvt.Ltd
}

\author{
Dr.D. Yuvaraju \& Dr.D. Subramanyam, Prof. S. Durga Rao \\ Department of Management Studies S.V. University, Tirupati- 517502. \\ Department of Economics, S.V. University, Tirupati- 517502 \\ Department of Management Studies S.V. University, Tirupati- 517502
}

\begin{abstract}
The study has helped me to measure the consumer awareness and impact of Advertisement on consumer buying decision. Study has made me to identify and understand the role of different media channels in advertising strategy. The coke advertisements are understandable and genuine. The large participants in the study said that they read coke ad in Eenadu. Star Gold occupied the first place in Hindi TV Channels and Teja TV stood first in Telugu T V channels. Though the Company performance is good it should pay more attention on designing innovative and unique advertisements.
\end{abstract}

\section{INTRODUCTION}

Advertising is a persuasive communication attempt to change or reinforce ones' prior attitude that is predictable of future behavior. We are not born with the attitudes which we hold toward various objects in our environment. Rather, we learn our feelings of favorability or not favorability through information about the attitude object (e.g., advertising), or direct experience with the attitude object (e.g., tasting a new brand of beer), or some combination of the two. Attitudes are not overt behaviors but rather are covert, or unobservable, internal reactions. Furthermore, once a certain type of attitudes are formed and repeatedly reinforced, the attitude toward objects is stored in consumers' memory as a form of either explicit or implicit memory. And those episodes of attitudes are retrieved automatically or strategically at the time of decision making, which generate certain types of reactions. Given that attitudes have traditionally been viewed as evaluations that are stored in memory and persist over time, the constructs of memory and attitude are extremely valuable construct to understand how advertising work. Also, the discussion about the underlying mechanisms of forming attitude and memory should be addressed. Therefore, I suggest a framework of "how advertising works" which starts from how consumers perceive advertising stimuli to the very last step of the impact of advertising on consumers' behavior.

Stages of Advertising Strategy: As a business begins, one of the major goals of advertising must be to generate awareness of the business and its products. Once the business' reputation is established and its products are positioned within the market, the amount of resources used for advertising will decrease as the consumer develops a kind of loyalty to the product. Ideally, this established and ever-growing consumer base will eventually aid the company in its efforts to carry their advertising message out into the market, both through its purchasing actions and its testimonials on behalf of the product or service. Essential to this rather abstract process is the development of a "positioning statement," as defined by Gerald E. Hills in "Marketing Option and Marketing" in The Portable MBA in Entrepreneurship: "A 'positioning statement' explains how a company's product (or service) is differentiated from those of key competitors." With this statement, the business owner turns intellectual objectives into concrete plans. In addition, this statement acts as the foundation for the development of a selling proposal, which is composed of the elements that will make up the advertising message's "copy platform." This platform delineates the images, copy, and art work that the business owner believes will sell the product. With these concrete objectives, the following elements of the advertising strategy need to be considered: target audience, product concept, communication media, and advertising message. These elements are at the core of an advertising strategy, and are often referred to as the "creative mix." Again, what most advertisers stress from the beginning is clear planning and flexibility? And key to these aims is creativity, and the ability to adapt to new market trends. A rigid advertising strategy often leads to a loss of market share. Therefore, the core elements of the advertising strategy need to mix in a way that allows the message to envelope the target consumer, providing ample opportunity for this consumer to become acquainted with the advertising message.

\section{Products and brands}

Diet Coke was introduced in 1982 to offer an alternative to dieters worried about the high number of calories present in regular Coca-Cola. Main article: Coca-Cola brands. The Coca-Cola Company offers nearly 400 brands in over 200 countries, besides its namesake Coca-Cola beverage. This includes other varieties of 
Coca-Cola such as: Diet Coke (introduced in 1982), which uses aspartame, a synthetic phenylalanine-based sweetener in place of sugar ,Diet Coke Caffeine-Free, Cherry Coke (1985), Diet Cherry Coke (1986),Coke with Lemon (2001) ,Diet Coke with Lemon (2001), Vanilla Coke (2002),Diet Vanilla Coke (2002),Coca-Cola C2 (2004),Coke with Lime (2004),Diet Coke with Lime (2004),Diet Coke Sweetened with Splenda (2005), CocaCola Zero (2005),Coca-Cola Black Cherry Vanilla (2006),Diet Coca-Cola Black Cherry Vanilla (2006) ,CocaCola Black (2006),Diet Coke Plus (2007) ,Coca-Cola Orange (2007),Summer Of US Coke Range (2007-2008)

Growth Rate of Coca-Cola in India: Coca Cola posted 8 per cent volume growth in the October-December quarter in India but its business in the country was slower during 2013 than in recent years amidst slowing economic environment. The Atlanta-based company that posted a net income of USD 1.7 billion during the fourth quarter, down 8 per cent from USD 1.86 billion in the year-ago period, said India, China and Japan led the firm's volume growth in its Pacific group. "Our Pacific Group's volume grew 4 per cent in the quarter, representing a sequential improvement versus the third quarter year-to-date results. Growth was broad based with 8 per cent growth in India, 5 per cent growth in China and 3 per cent growth in Japan," it said in a statement. This marked Coca-Cola India's 30th consecutive quarter of growth, 19 of which are double digits. Coca Cola's overall net operating revenues were down 4 per cent to USD 11.040 billion from USD 11.455 billion in the fourth quarter. Its Bottling Investments Group's (BIG) volume grew 7 per cent in the quarter on a comparable basis, led by Germany, China and India, after adjusting for the net impact of structural changes, primarily the deconsolidation of the Philippine and Brazilian bottling operations in 2013. The slowdown in the Indian economy, however, had its impact on its volume sales on a yearly basis. "Our China and India businesses both grew slower than in recent years amidst slowing economic environments, but saw stronger performance in the second half of the year due to a focus on execution and normalized weather," the company said. The CocaCola Company Chairman and Chief Executive Officer Muhtar Kent said: "2013 was marked by ongoing global macroeconomic challenges in many markets around the world. And while our business was not immune to these pressures leading to moderated global volume growth, we delivered sound financial results in line with our long-term profit targets..." The company gained global value share in total non- alcoholic ready-to-drink beverages as well as global volume and value share in core sparkling and still beverages for the year, he added.

On the outlook, Kent said: "A rising middle class, greater urbanization and increasing personal consumption expenditures in markets around the world will continue to drive greater demand for our beverages as consumers look for moments of refreshment. As we work to restore momentum in our business during 2014, we see many reasons to believe we can accelerate our growth..." Coca Cola further said it expects to save USD 1 billion through its productivity enhancement by 2016 that will be redirected primarily into increased media investments such as advertising. The Atlanta-based company that posted a net income of USD 1.7 billion during the fourth quarter, down 8 per cent from USD 1.86 billion in the year-ago period, said India, China and Japan led the firm's volume growth in its Pacific group. "Our Pacific Group's volume grew 4 per cent in the quarter, representing a sequential improvement versus the third quarter year-to-date results. Growth was broad based with 8 per cent growth in India, 5 per cent growth in China and 3 per cent growth in Japan," it said in a statement. This marked Coca-Cola India's 30th consecutive quarter of growth, 19 of which are double digits. Coca Cola's overall net operating revenues were down 4 per cent to USD 11.040 billion from USD 11.455 billion in the fourth quarter. Its Bottling Investments Group's (BIG) volume grew 7 per cent in the quarter on a comparable basis, led by Germany, China and India, after adjusting for the net impact of structural changes, primarily the deconsolidation of the Philippine and Brazilian bottling operations in 2013. The slowdown in the Indian economy, however, had its impact on its volume sales on a yearly basis."Our China and India businesses both grew slower than in recent years amidst slowing economic environments, but saw stronger performance in the second half of the year due to a focus on execution and normalized weather," the company said. The CocaCola Company Chairman and Chief Executive Officer Muhtar Kent said: "2013 was marked by ongoing global macroeconomic challenges in many markets around the world. And while our business was not immune to these pressures leading to moderated global volume growth, we delivered sound financial results in line with our long-term profit targets..." The company gained global value share in total non- alcoholic ready-to-drink beverages as well as global volume and value share in core sparkling and still beverages for the year, he added. On the outlook, Kent said: "A rising middle class, greater urbanization and increasing personal consumption expenditures in markets around the world will continue to drive greater demand for our beverages as consumers look for moments of refreshment. As we work to restore momentum in our business during 2014, we see many reasons to believe we can accelerate our growth..." Coca Cola further said it expects to save USD 1 billion through its productivity enhancement by 2016 that will be redirected primarily into increased media investments such as advertising. Its Bottling Investments Group's (BIG) volume grew 7 per cent in the quarter on a comparable basis, led by Germany, China and India, after adjusting for the net impact of structural changes, primarily the deconsolidation of the Philippine and Brazilian bottling operations in 2013. The slowdown in the Indian economy, however, had its impact on its volume sales on a yearly basis. "Our China and India businesses 
both grew slower than in recent years amidst slowing economic environments, but saw stronger performance in the second half of the year due to a focus on execution and normalized weather," the company said. The CocaCola Company Chairman and Chief Executive Officer Muhtar Kent said: "2013 was marked by ongoing global macroeconomic challenges in many markets around the world. And while our business was not immune to these pressures leading to moderated global volume growth, we delivered sound financial results in line with our long-term profit targets..." The company gained global value share in total non- alcoholic ready-to-drink beverages as well as global volume and value share in core sparkling and still beverages for the year, he added. On the outlook, Kent said: "A rising middle class, greater urbanization and increasing personal consumption expenditures in markets around the world will continue to drive greater demand for our beverages as consumers look for moments of refreshment. As we work to restore momentum in our business during 2014, we see many reasons to believe we can accelerate our growth..." Coca Cola further said it expects to save USD 1 billion through its productivity enhancement by 2016 that will be redirected primarily into increased media investments such as advertising.

\section{Objectives}

1. To analyze the impact of advertisement on consumer buying decision

2. To find out the most popular advertisement media.

\section{Need for the study}

The current study intends to measure the impact of Coke advertisements on consumer buying decisions. It is known fact that the recent Coke advertisements which are endorsed by Film and Cricket Stars have become very popular. In this context there is a need to understand how far the awareness created by these advertisements help company to increase its sales.

\section{Methodology}

Sample method

A random sampling method was used for the purpose of this study. Data were collected from both Consumers and non Consumers of Coke. Sample size is 87.

\section{Data collection}

For the purpose of the study data has been collected through two sources among that

1) Primary source

2) Secondary source

Data sources:

Secondary data:

For the secondary source I collected information from the company websites, company broachers, from journals and articles about the company

\section{Primary data:}

For the primary source data is collected through structured questionnaire,

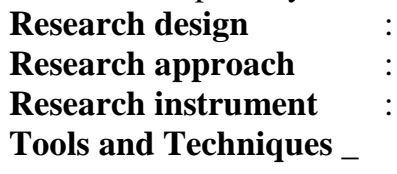
Descriptive Research Survey Method Questionnaire Tools and Techniques _ Data has been analyzed using frequency tables, cross tabulations.

\section{Limitations}

As the data has been collected from the existing Consumers of Coke, their tastes and preferences towards the soft drink may have influenced current opinions. Questionnaires were administered at few public places and hotels and restaurants. Timing of questionnaire administration may have influenced the data

Data Analysis and Interpretation

Table 1: Gender * Age Cross tabulation

\begin{tabular}{|l|l|l|l|l|l|l|}
\hline \multicolumn{2}{|c|}{} & \multicolumn{2}{|l|}{ Age } & \multicolumn{2}{l|}{} \\
\cline { 2 - 8 } \multicolumn{2}{|c|}{} & $<20$ yrs & $20-30$ yrs & $30-40$ yrs & >40 yrs & Total \\
\hline \multirow{3}{*}{ Gender } & Male & 1 & 29 & 11 & 6 & 47 \\
\cline { 2 - 8 } & Female & 8 & 29 & 3 & 0 & 40 \\
\hline
\end{tabular}




\begin{tabular}{|l|l|l|l|l|l|}
\hline Total & 9 & 58 & 14 & 6 & 87 \\
\hline
\end{tabular}

Interpretation: The above table shows the gender-age wise classification of the total respondents. Out of 87 respondents, 47 were male and 40 were female. Among the 87 respondents, 58 lie in the age-group of 20$30 \mathrm{yrs}$ and 14 lie in the age group of 30-40 yrs.

Table 2: Gender * Marital status Cross tabulation

\begin{tabular}{|l|l|l|l|l|}
\hline \multicolumn{2}{|c|}{} & \multicolumn{2}{|l|}{ Marital status } & \multirow{2}{*}{ Total } \\
\cline { 3 - 5 } \multicolumn{2}{c|}{ Gender } & Married & Unmarried & 47 \\
\cline { 2 - 5 } & Male & 27 & 20 & 40 \\
\hline Total & Female & 32 & 8 & 87 \\
\hline
\end{tabular}

Interpretation: The above table shows the gender-marital status wise classification of the total respondents. Out of 87 respondents, 47 were male and 40 were female. Among the 87 respondents, 59 were married and 28 were unmarried.

Table 3: Gender * Monthly Family income Cross tabulation

\begin{tabular}{|c|c|c|c|c|c|c|}
\hline & \multicolumn{4}{|c|}{ Monthly Family income } & \multirow[b]{2}{*}{ Total } \\
\hline & & $<10000$ & $10000-15000$ & $15000-20000$ & $>20000$ & \\
\hline \multirow[t]{2}{*}{ Gender } & Male & 9 & 10 & 17 & 11 & 47 \\
\hline & Female & 1 & 6 & 25 & 8 & 40 \\
\hline \multicolumn{2}{|l|}{ Total } & 10 & 16 & 42 & 19 & 87 \\
\hline
\end{tabular}

Interpretation: The above table shows the gender-monthly income wise classification of the total respondents. Out of 87 respondents, 47 were male and 40 were female. Among the 87 respondents, 42 have a monthly income of 15,000-20,000 and 19 have an monthly income of $>20,000$.

Table 4: Age * Marital status Cross tabulation

\begin{tabular}{|c|c|c|c|c|}
\hline & \multicolumn{2}{|c|}{ Marital status } & \multirow[b]{2}{*}{ Total } \\
\hline & & Married & Unmarried & \\
\hline \multirow[t]{4}{*}{ Age } & $<20$ yrs & 0 & 9 & 9 \\
\hline & 20-30 yrs & 39 & 19 & 58 \\
\hline & $30-40$ yrs & 14 & $\mathbf{0}$ & 14 \\
\hline & $>40$ yrs & 6 & $\mathbf{0}$ & 6 \\
\hline \multicolumn{2}{|c|}{ Total } & 59 & 28 & 87 \\
\hline
\end{tabular}

Interpretation: The above table shows the age-marital status wise classification of the total respondents. Out of 87 respondents, 58 lie in the age-group of 20-30 yrs and 14 lie in the age-group of 30-40 yrs. Among the 87 respondents, 59 were married and 28 were unmarried.

Table 5: Age * Monthly Family income Cross tabulation

\begin{tabular}{|c|c|c|c|c|c|c|}
\hline & \multicolumn{4}{|c|}{ Monthly Family income } & \multirow[b]{2}{*}{ Total } \\
\hline & & $<10000$ & $\begin{array}{l}10000- \\
15000\end{array}$ & $\begin{array}{l}15000- \\
20000\end{array}$ & $>20000$ & \\
\hline \multirow[t]{4}{*}{ Age } & $<20$ yrs & 1 & 3 & 4 & 1 & 9 \\
\hline & 20-30 yrs & 7 & 9 & 30 & 12 & 58 \\
\hline & $30-40$ yrs & $\mathbf{0}$ & $\mathbf{0}$ & 8 & 6 & 14 \\
\hline & $>40 \mathrm{yrs}$ & 2 & 4 & $\mathbf{0}$ & $\mathbf{0}$ & 6 \\
\hline \multicolumn{2}{|c|}{ Total } & 10 & 16 & 42 & 19 & 87 \\
\hline
\end{tabular}

Interpretation: The above table shows the age-monthly income wise classification of the total respondents. Out of 87 respondents, 58 lie in the age-group of 20-30 yrs and 14 lie in the age-group of 30-40 yrs. Among the 87 respondents, 42 have a monthly income of 15,000-20,000 and 19 have a monthly income of $>20,000$. 
Table 6: Marital status * Monthly Family income Cross tabulation

\begin{tabular}{|l|l|l|l|l|l|l|}
\hline \multirow{2}{*}{\multicolumn{2}{|c|}{}} & \multicolumn{4}{|l|}{ Monthly Family income } & \multirow{2}{*}{} \\
\cline { 3 - 7 } \multicolumn{2}{|c|}{} & $<10000$ & $\begin{array}{l}10000- \\
15000\end{array}$ & $\begin{array}{l}15000- \\
20000\end{array}$ & $>20000$ & Total \\
\hline $\begin{array}{l}\text { Marital } \\
\text { status }\end{array}$ & Married & 2 & 7 & 36 & 14 & 59 \\
\hline & Unmarried & 8 & 9 & 6 & 5 & 28 \\
\hline Total & 10 & 16 & 42 & 19 & 87 \\
\hline
\end{tabular}

Interpretation: The above table shows the marital status-monthly income wise classification of the total respondents. Out of 87 respondents, 59 were married and 28 were unmarried. Among the 87 respondents, 42 have a monthly income of 15,000-20,000 and 19 have a monthly income of $>20,000$.

\section{Frequencies:}

Table 7: In the last two months where you saw / listen to coke advertisement

\begin{tabular}{|l|l|l|l|l|l|}
\hline \multicolumn{2}{|l|}{} & Frequency & Percent & $\begin{array}{l}\text { Valid } \\
\text { Percent }\end{array}$ & $\begin{array}{l}\text { Cumulative } \\
\text { Percent }\end{array}$ \\
\hline Valid & Newspaper & 16 & 18.4 & 18.4 & 18.4 \\
\hline & $\begin{array}{l}\text { TV } \\
\text { Commercial }\end{array}$ & 26 & 29.9 & 29.9 & 48.3 \\
\hline & Hoardings & 26 & 29.9 & 29.9 & 78.2 \\
\hline & Leaflets & 11 & 12.6 & 12.6 & 90.8 \\
\hline & FM Radio & 8 & 9.2 & 9.2 & 100.0 \\
\hline & Total & 87 & 100.0 & 100.0 & \\
\hline
\end{tabular}

Interpretation: The above table shows that 26 i.e. $29.9 \%$ of the total respondents saw the coke advertisement on the hoardings and equal number of respondents saw/listened the advertisement in the Television. And 16 i.e. $18.4 \%$ of the total respondents saw the advertisement in the news papers.

Table 8: In which Telugu news paper you find more coke ads

\begin{tabular}{|l|l|l|l|l|l|}
\hline \multicolumn{2}{|c|}{} & Frequency & Percent & Valid Percent & $\begin{array}{l}\text { Cumulative } \\
\text { Percent }\end{array}$ \\
\hline Valid & Vaartha & 16 & 18.4 & 18.4 & 18.4 \\
\cline { 2 - 6 } & $\begin{array}{l}\text { Andhra } \\
\text { Jyothi }\end{array}$ & 21 & 24.1 & 24.1 & 42.5 \\
\cline { 2 - 6 } & Eenadu & 50 & 57.5 & 57.5 & 100.0 \\
\cline { 2 - 6 } & Total & 87 & 100.0 & 100.0 & \\
\hline
\end{tabular}

Interpretation: The above table shows that 50 i.e.57.5\% of the total respondents found more coke advertisements in the Eenadu newspaper, 21 i.e. 24.1\% found more coke advertisements in Andhra Jyothi and 16 i.e. $18.4 \%$ of the total respondents found more coke advertisements in the Vaartha newspaper.

Table 9: In which Telugu TV Channel you find more coke ads

\begin{tabular}{|l|l|l|l|l|l|}
\hline \multicolumn{2}{|c|}{} & Frequency & Percent & Valid Percent & $\begin{array}{l}\text { Cumulative } \\
\text { Percent }\end{array}$ \\
\hline \multirow{7}{*}{ Valid } & T V 9 & 4 & 4.6 & 4.6 & 4.6 \\
\cline { 2 - 6 } & ETV & 24 & 27.6 & 27.6 & 32.2 \\
\cline { 2 - 6 } & TEJA & 59 & 67.8 & 67.8 & 100.0 \\
\cline { 2 - 6 } & Total & 87 & 100.0 & 100.0 & \\
\hline
\end{tabular}

Interpretation: The above table shows that 59 i.e.67.8\% of the total respondents found more coke advertisements in TEJA TV, 24 i.e. $27.6 \%$ found more coke advertisements in ETV.

Table 10: In which English Newspaper you find more coke ads 


\begin{tabular}{|l|l|l|l|l|l|}
\hline \multicolumn{2}{|l|}{} & Frequency & Percent & Valid Percent & $\begin{array}{l}\text { Cumulative } \\
\text { Percent }\end{array}$ \\
\hline Valid & The Hindu & 14 & 16.1 & 16.1 & 16.1 \\
\hline & Deccan Chronicle & 33 & 37.9 & 37.9 & 54.0 \\
\hline & Times of India & 31 & 35.6 & 35.6 & 89.7 \\
\hline & Indian Express & 9 & 10.3 & 10.3 & 100.0 \\
\hline & Total & 87 & 100.0 & 100.0 & \\
\hline
\end{tabular}

Interpretation: The above table shows that 33 i.e.37.9 \% of the total respondents found more coke advertisements in the Deccan Chronicle newspaper, 31 i.e. $35.6 \%$ found more coke advertisements in Times of India and 14 i.e. $16.1 \%$ of the total respondents found more coke

Table 11: In which Hindi TV Channel you find more coke ads

\begin{tabular}{|l|l|l|l|l|l|}
\hline \multicolumn{2}{|c|}{} & Frequency & Percent & $\begin{array}{l}\text { Valid } \\
\text { Percent }\end{array}$ & $\begin{array}{l}\text { Cumulative } \\
\text { Percent }\end{array}$ \\
\hline \multirow{3}{*}{ Valid } & Set Max & 18 & 20.7 & 20.7 & 20.7 \\
\cline { 2 - 6 } & Star Gold & 46 & 52.9 & 52.9 & 73.6 \\
\cline { 2 - 6 } & Zee & 21 & 24.1 & 24.1 & 97.7 \\
\cline { 2 - 6 } & Star Plus & 2 & 2.3 & 2.3 & 100.0 \\
\cline { 2 - 6 } & Total & 87 & 100.0 & 100.0 & \\
\hline
\end{tabular}

Interpretation: The above table shows that 46 i.e.52.9\% of the total respondents found more coke advertisements in STAR GOLD, 21 i.e. $24.1 \%$ found more coke advertisements in ZEE. And the remaining found more coke advertisements in SET MAX.

Table 12: How well do you remember recent coke ad

\begin{tabular}{|c|c|c|c|c|c|}
\hline & & Frequency & Percent & $\begin{array}{l}\text { Valid } \\
\text { Percent }\end{array}$ & $\begin{array}{l}\text { Cumulative } \\
\text { Percent }\end{array}$ \\
\hline \multirow[t]{5}{*}{ Valid } & $\begin{array}{l}\text { Don't } \\
\text { remember } \\
\text { at all }\end{array}$ & 6 & 6.9 & 6.9 & 6.9 \\
\hline & $\begin{array}{l}\text { Remember } \\
\text { company } \\
\text { but not } \\
\text { product or } \\
\text { ad }\end{array}$ & 13 & 14.9 & 14.9 & 21.8 \\
\hline & $\begin{array}{l}\text { Remember } \\
\text { company } \\
\text { and } \\
\text { product } \\
\text { but not ad }\end{array}$ & 21 & 24.1 & 24.1 & 46 \\
\hline & $\begin{array}{l}\text { Remember } \\
\text { ad }\end{array}$ & 47 & 54 & 54 & 100 \\
\hline & Total & 87 & 100 & 100 & \\
\hline
\end{tabular}

Interpretation: The above table shows that 47 i.e. $54.0 \%$ of the total respondents say that they remember the advertisement and 21 i.e. $24.1 \%$ of the total respondents say that they remember the company and the product but not the advertisement. 6 respondents, i.e.6.9\% of them say that they do not remember the advertisement.

Table 13: If you were describing this ad to a friend, would you say this ad is....

\begin{tabular}{|l|l|l|l|l|}
\hline & & & Cumulative \\
& Frequency & Percent & Valid Percent & Percent \\
\hline
\end{tabular}




\begin{tabular}{|l|l|l|l|l|l|}
\hline Valid & Active & 8 & 9.2 & 9.2 & 9.2 \\
\cline { 2 - 6 } & $\begin{array}{l}\text { Attention- } \\
\text { getting }\end{array}$ & 49 & 56.3 & 56.3 & 65.5 \\
\cline { 2 - 6 } & Boring & 7 & 8.0 & 8.0 & 73.6 \\
\cline { 2 - 6 } & Cheerful & 5 & 5.7 & 5.7 & 79.3 \\
\cline { 2 - 6 } & Creative & 18 & 20.7 & 20.7 & 100.0 \\
\cline { 2 - 6 } & Total & 87 & 100.0 & 100.0 & \\
\hline
\end{tabular}

Interpretation: The above table shows that 49 i.e. $56.3 \%$ of the total respondents say that they would describe this ad to a friend as attention-getting and 18 i.e. $20.7 \%$ of the total respondents say that they would describe this ad to a friend as creative and 7 i.e.8.0\% of the total respondents would describe this ad to a friend as boring.

Table 14: The ad Message is understandable.

\begin{tabular}{|l|l|l|l|l|l|}
\hline \multicolumn{2}{|c|}{} & Frequency & Percent & $\begin{array}{l}\text { Valid } \\
\text { Percent }\end{array}$ & $\begin{array}{l}\text { Cumulative } \\
\text { Percent }\end{array}$ \\
\hline Valid & $\begin{array}{l}\text { Strongly } \\
\text { Agree }\end{array}$ & 68 & 78.2 & 78.2 & 78.2 \\
\cline { 2 - 6 } & $\begin{array}{l}\text { Somewhat } \\
\text { Agree }\end{array}$ & 12 & 13.8 & 13.8 & 92.0 \\
\cline { 2 - 6 } & Neither & 7 & 8.0 & 8.0 & 100.0 \\
\cline { 2 - 6 } & Total & 87 & 100.0 & 100.0 & \\
\hline
\end{tabular}

Interpretation: The above table shows that 68 i.e. $78.2 \%$ of the total respondents strongly agree that the ad message was understandable and 12 i.e. $13.8 \%$ of the total respondents somewhat agree that the ad message was understandable.

Table 15: If you were describing this ad to a friend, would you say this ad is...

\begin{tabular}{|l|l|l|l|l|l|}
\hline \multicolumn{2}{|l|}{} & Frequency & Percent & $\begin{array}{l}\text { Valid } \\
\text { Percent }\end{array}$ & $\begin{array}{l}\text { Cumulative } \\
\text { Percent }\end{array}$ \\
\hline Valid & Emotional & 15 & 17.2 & 17.2 & 17.2 \\
\hline & Energetic & 14 & 16.1 & 16.1 & 33.3 \\
\hline & $\begin{array}{l}\text { Genuine/sin } \\
\text { cere }\end{array}$ & 35 & 40.2 & 40.2 & 73.6 \\
\hline & Honest & 23 & 26.4 & 26.4 & 100.0 \\
\hline & Total & 87 & 100.0 & 100.0 & \\
\hline
\end{tabular}

Interpretation: The above table shows that 35 i.e. $40.2 \%$ of the total respondents say that they would describe this ad to a friend as genuine/sincere and 23 i.e. $26.4 \%$ of the total respondents say that they would describe this ad to a friend as honest and 14 i.e. $16.1 \%$ of the total respondents would describe this ad to a friend as energetic.

Table 16: The advertisement is believable

\begin{tabular}{|l|l|l|l|l|l|}
\hline \multicolumn{2}{|c|}{} & Frequency & Percent & $\begin{array}{l}\text { Valid } \\
\text { Percent }\end{array}$ & $\begin{array}{l}\text { Cumulative } \\
\text { Percent }\end{array}$ \\
\hline \multirow{3}{*}{ Valid } & Strongly Agree & 5 & 5.7 & 5.7 & 5.7 \\
\cline { 2 - 6 } & Somewhat Agree & 71 & 81.6 & 81.6 & 87.4 \\
\cline { 2 - 6 } & Neither & 11 & 12.6 & 12.6 & 100.0 \\
\cline { 2 - 6 } & Total & 87 & 100.0 & 100.0 & \\
\hline
\end{tabular}

Interpretation: The above table shows that only 5 i.e. $5.7 \%$ of the total respondents strongly agree that the ad is believable and 71 i.e. $81.6 \%$ of the total respondents somewhat agree that the ad is believable.

Table 17: The ads message is relevant to me

\begin{tabular}{|l|l|l|l|l|}
\hline & & Valid & Cumulative \\
& Frequency & Percent & Percent & Percent \\
\hline
\end{tabular}




\begin{tabular}{|l|l|l|l|l|l|}
\hline Valid & $\begin{array}{l}\text { Strongly } \\
\text { Agree }\end{array}$ & 5 & 5.7 & 5.7 & 5.7 \\
\hline & $\begin{array}{l}\text { Somewhat } \\
\text { Agree }\end{array}$ & 26 & 29.9 & 29.9 & 35.6 \\
\hline & Neither & 50 & 57.5 & 57.5 & 93.1 \\
\hline & $\begin{array}{l}\text { Somewhat } \\
\text { Disagree }\end{array}$ & 6 & 6.9 & 6.9 & 100.0 \\
\hline & Total & 87 & 100.0 & 100.0 & \\
\hline
\end{tabular}

Interpretation: The above table shows that 50 i.e. $57.5 \%$ of the total respondents neither agree nor disagree that the ad message was relevant to them and 26 i.e. $29.9 \%$ of the total respondents somewhat agree that the ad message was relevant to them.

Table 18: If you were describing this ad to a friend, would you say this ad is....

\begin{tabular}{|l|l|l|l|l|l|}
\hline \multicolumn{2}{|c|}{} & Frequency & Percent & $\begin{array}{l}\text { Valid } \\
\text { Percent }\end{array}$ & $\begin{array}{l}\text { Cumulative } \\
\text { Percent }\end{array}$ \\
\hline Valid & $\begin{array}{l}\text { Informati } \\
\text { ve }\end{array}$ & 53 & 60.9 & 60.9 & 60.9 \\
\cline { 2 - 6 } & Irritating & 3 & 3.4 & 3.4 & 64.4 \\
\cline { 2 - 6 } & $\begin{array}{l}\text { Memorab } \\
\text { le }\end{array}$ & 15 & 17.2 & 17.2 & 81.6 \\
\cline { 2 - 6 } & Natural & 16 & 18.4 & 18.4 & 100.0 \\
\cline { 2 - 6 } & Total & 87 & 100.0 & 100.0 & \\
\hline
\end{tabular}

Interpretation: The above table shows that 53 i.e. $60.9 \%$ of the total respondents say that they would describe this ad to a friend as informative and 16 i.e. $18.4 \%$ of the total respondents say that they would describe this ad to a friend as natural and 15 i.e. $17.2 \%$ of the total respondents would describe this ad to a friend as memorable.

Table 19: The benefits described in the ad are believable to me

\begin{tabular}{|l|l|l|l|l|l|}
\hline \multicolumn{2}{|c|}{} & Frequency & Percent & $\begin{array}{l}\text { Valid } \\
\text { Percent }\end{array}$ & $\begin{array}{l}\text { Cumulative } \\
\text { Percent }\end{array}$ \\
\hline \multirow{7}{*}{ Valid } & Strongly Agree & 5 & 5.7 & 5.7 & 5.7 \\
\cline { 2 - 6 } & Somewhat Agree & 29 & 33.3 & 33.3 & 39.1 \\
\cline { 2 - 6 } & Neither & 31 & 35.6 & 35.6 & 74.7 \\
\cline { 2 - 6 } & Somewhat disagree & 9 & 10.3 & 10.3 & 85.1 \\
\cline { 2 - 6 } & Strongly Disagree & 13 & 14.9 & 14.9 & 100.0 \\
\cline { 2 - 6 } & Total & 87 & 100.0 & 100.0 & \\
\hline
\end{tabular}

Interpretation: The above table shows that only 5 i.e. $5.7 \%$ of the total respondents strongly agree that the benefits described in the ad is believable and 29 i.e. $33.3 \%$ of the total respondents somewhat agree that the benefits described in the ad is believable.

Table 20: If you were describing this ad to a friend, would you say this ad is.

\begin{tabular}{|l|l|l|l|l|l|}
\hline \multicolumn{2}{|c|}{} & Frequency & Percent & $\begin{array}{l}\text { Valid } \\
\text { Percent }\end{array}$ & $\begin{array}{l}\text { Cumulative } \\
\text { Percent }\end{array}$ \\
\hline \multirow{3}{*}{ Valid } & Pleasant & 1 & 1.1 & 1.1 & 1.1 \\
\cline { 2 - 6 } & Satisfying & 60 & 69.0 & 69.0 & 70.1 \\
\cline { 2 - 6 } & Strong & 9 & 10.3 & 10.3 & 80.5 \\
\cline { 2 - 6 } & Unique & 17 & 19.5 & 19.5 & 100.0 \\
\cline { 2 - 6 } & Total & 87 & 100.0 & 100.0 & \\
\hline
\end{tabular}

Interpretation: The above table shows that 60 i.e. $69.0 \%$ of the total respondents say that they would describe this ad to a friend as satisfying and 17 i.e. $19.5 \%$ of the total respondents say that they would describe this ad to a friend as unique and 9 i.e. $10.3 \%$ of the total respondents would describe this ad to a friend as strong.

Table 21: After viewing this ad, I would consider purchasing the product.

\begin{tabular}{|l|l|l|l|l|}
\hline & & & Valid & Cumulative \\
& Frequency & Percent & Percent \\
\hline
\end{tabular}




\begin{tabular}{|l|l|l|l|l|l|}
\hline Valid & Strongly Agree & 59 & 67.8 & 67.8 & 67.8 \\
\cline { 2 - 6 } & Somewhat Agree & 26 & 29.9 & 29.9 & 97.7 \\
\cline { 2 - 6 } & Neither & 1 & 1.1 & 1.1 & 98.9 \\
\cline { 2 - 6 } & strongly Disagree & 1 & 1.1 & 1.1 & 100.0 \\
\cline { 2 - 6 } & Total & 87 & 100.0 & 100.0 & \\
\hline
\end{tabular}

Interpretation: The above table shows that 59 i.e. $67.8 \%$ of the total respondents strongly agree that after viewing the advertisement they would purchase the product and 26 i.e. $29.9 \%$ of the total respondents somewhat agree with the above.

Table 22: This ad is much better than other ads for products in this product category.

\begin{tabular}{|l|l|l|l|l|l|}
\hline \multicolumn{2}{|c|}{} & Frequency & Percent & $\begin{array}{l}\text { Valid } \\
\text { Percent }\end{array}$ & $\begin{array}{l}\text { Cumulative } \\
\text { Percent }\end{array}$ \\
\hline \multirow{4}{*}{ Valid } & Strongly Agree & 9 & 10.3 & 10.3 & 10.3 \\
\cline { 2 - 6 } & Somewhat Agree & 1 & 1.1 & 1.1 & 11.5 \\
\cline { 2 - 6 } & Neither & 55 & 63.2 & 63.2 & 74.7 \\
\cline { 2 - 6 } & Somewhat Disagree & 17 & 19.5 & 19.5 & 94.3 \\
\cline { 2 - 6 } & Strongly Disagree & 5 & 5.7 & 5.7 & 100.0 \\
\cline { 2 - 6 } & Total & 87 & 100.0 & 100.0 & \\
\hline
\end{tabular}

Interpretation: The above table shows that 55 i.e. $63.2 \%$ of the total respondents neither agree nor disagree that the ad is much better than the other ads for products in the same category and 17 i.e. $19.5 \%$ of the total respondents somewhat agree with the above.

\section{FINDINGS}

- The study has helped me to measure the consumer awareness and impact of Advertisement on consumer buying decision.

- Study has made me to identify and understand the role of different media channels in advertising strategy.

- $\quad$ The coke advertisements are understandable and genuine.

- The large participants in the study said that they read coke ad in Eenadu.

- Star Gold occupied the first place in Hindi TV Channels and Teja TV stood first in Telugu T V channels.

- Though the Company performance is good it should pay more attention on designing innovative and unique advertisements.

\section{SUGGESTIONS}

- Company should pay more attention on designing innovative and unique advertisements.

- $\quad$ Benefits described in the ad need to relevant and pertinent to the consumers and situations.

- Instead of exaggerating the situations in the ad, company should pay more attention towards pragmatic situations.

\section{CONCLUSION}

- This study has been conducted to measure the consumer awareness and impact of advertisement on consumer buying decision. This study also tried to understand the role and importance of various media channels.

- Consumers participated in the study are of the opinion that the message sent through coke advertisements are understandable and genuine. They also expressed their satisfaction with regard to the information provided through ads.

- After watching or listening or reading the coke ads that are endorsed by various brand ambassadors like, Amir Khan, Hrithik Roshan, Mahesh Babu and Cricket stars, consumers expressed their willingness to purchase coke.

- Majority of the participants in the study said that they read coke ad in Eenadu which is followed by Andhra Jyothi. As far as English newspapers are concerned Deccan Chronicle stood in first place which is followed by Times of India

- Star Gold occupied the first place in Hindi TV Channels and Teja TV stood first in Telugu T V channels. 
- However, the slip side findings of the study are consumers don't believe the adventures carried out by the celebrities in the ads and they are not trusting the benefits described in the ad.

\section{References}

[1]. Marketing Management by Philip Kotlar

[2]. Marketing Research by Aekar, Kumar \& Day

[3]. Marketing Research by Hair, Bush \& Ortinau

[4]. www.Cocacola.com

[5]. www.softdrinks.com

[6]. http://articles.economictimes.indiatimes.com/2014-02-18/news/47451386_1_coca-cola-companychairman-coca-cola-india-volume-growth 